\section{Effect of Different Commercial Substrates on Growth of Petunia Transplants}

\author{
Yuqi $\mathrm{Li}^{1}$ and Neil S. Mattson ${ }^{2,3}$
}

\begin{abstract}
Additional Index words. Petunia $\times$ bybrida, growing media, fertigation, floriculture

Summary. The objective of this study was to evaluate the growth and flowering of petunia (Petunia $\times$ bybrida) transplants in response to seven commercial substrates with two water sources (fertigation and clear water irrigation). Seven commercial substrates used were Sunshine \# I Natural \& Organic (SS), Metro-Mix 360 (MM), AgriTech (AT), Cornell Peat-Lite Mix B (CB), Jeff's Organic (JO), LM-18, and LM-111. The experiment was a completely randomized $2 \times 7$ factorial design with six single-pot replications per treatment. With fertigation, substrate electrical conductivity (EC) decreased over time to 38 days after transplanting (DAT), and then did not further change. The AT substrate EC value was greater than others during the first $38 \mathrm{DAT}$. With clear water irrigation, substrate $\mathrm{EC}$ decreased over time to $31 \mathrm{DAT}$, and then did not further change. The AT substrate EC value was greater than other substrates during the entire petunia growth period. With fertigation, all substrate $\mathrm{pH}$ values were between 6.5 and 7.5 except AT and CB. The AT substrate had the greatest $\mathrm{pH}$ ranging from 7.5 to 8.0 during the petunia growth period. The $\mathrm{CB}$ substrate exhibited the lowest $\mathrm{pH}$, which was between 5.8 and 6.3. Clear water irrigation had greater substrate $\mathrm{pH}$ values than fertigation. There was a substrate and water interaction for calcium $(\mathrm{Ca})$, potassium $(\mathrm{K})$, ammonium-nitrogen $\left(\mathrm{NH}_{4}{ }^{+}-\mathrm{N}\right)$, nitrate-nitrogen $\left(\mathrm{NO}_{3}{ }^{-}-\mathrm{N}\right)$, and sodium $(\mathrm{Na})$ concentrations in substrate leachate. At $52 \mathrm{DAT}$, the shoot dry weight (DW), root index (RI), and flower number of petunia grown in AT substrate were greatest among all the substrates, but chlorophyll index (SPAD) was the lowest under either the fertigation or clear water irrigation treatments. The DW and RI of petunia grown in AT substrate were greater when fertigation was used than clear water irrigation, but the water source had no effect on flower number. For SS, MM, CB, JO, LM-18, and LM-111 substrates, fertigation increased petunia DW, RI, and flower number as compared with clear water irrigation, but not SPAD readings.
\end{abstract}

$\mathrm{F}$ or transportation cost and environmental concerns, there is increased pressure to use alternatives to peat as a substrate component and instead increase the use of waste materials, such as organic wastes that often go to landfills (Abad et al., 2002; Danaher et al., 2013; Garcia-Ortuño et al., 2012; Hernández-Apaolaza et al., 2005). Many substrate components exist for horticultural production, including low-cost, local peat alternatives such as sawdust, pine bark, coconut fiber, sewage sludge, chicken manure, and cattle manure (Ao et al., 2008; Hernández-Apaolaza et al., 2005). In addition, the limes and preplant nutrient charge fertilizers can be usually added in certain commercial substrates

Use of trade names does not imply an endorsement of the products named or criticism of similar ones not named.

${ }^{1}$ School of Chemical Engineering and Food Science, Hubei University of Arts and Science, Xiangyang, Hubei Province 441053, China

${ }^{2}$ Horticulture Section, School of Integrative Plant Science, Cornell University, Ithaca, NY 14853

${ }^{3}$ Corresponding author. E-mail: nsm47@cornell.edu. for requirement of plant growth (Argo and Biernbaum, 1996). These can result in different physical and chemical properties between commercial substrates, especially nutrient composition (Abad et al., 2002; Benito et al., 2006; Higashikawa et al., 2010). Higashikawa et al. (2010) systematically studied the chemical and physical properties of charcoal, coffee husk, pine bark, cattle manure, chicken manure, coconut fiber, sewage sludge, peat, and vermiculite. Results showed that coffee husk, sewage sludge, chicken manure, and cattle manure generally were richer in nutrients than others. The EC values of these residues were also the highest. Peat and sewage sludge had the greatest bulk density. The Na concentrations varied from 0 to $4.75 \mathrm{~g} \cdot \mathrm{kg}^{-1}$, with the greatest concentrations in chicken manure, cattle manure, and sewage sludge.

Different substrates contain different components that could have direct and/or indirect effects on plant growth and development (Ghehsareh et al., 2012). Zaller (2007) found that commercial peat potting substrates including vermicompost influenced, specifically for each tomato (Solanum lycopersicum) variety, emergence and elongation of seedlings. Tomato seedling growth was greatest after substituting $25 \%$ to $50 \%$ pig manure vermicompost for commercial substrate [MM; Sun Gro Horticulture, Agawam, MA (Atiyeh et al., 2001)]. Danaher et al. (2013) evaluated petunia growth response to amending a commercial potting mix (Fafard 3B; Conrad Fafard, Agawam, MA) with different amounts of dewatered aquaculture effluent. Growth of petunia was greatest after substitution of Fafard 3B with $25 \%$ dewatered aquaculture effluent. The fertility value of substrate amendments can also reduce the need for fertilizer additions (Raviv, 2013). Therefore, fertilizer regime should be reconsidered when switching substrates or substrate components. Petunia is one of the most popular bedding plants worldwide and the most popular bedding plant in the United States with an annual wholesale value of $\$ 130$ million (U.S. Department of Agriculture, 2014). Many greenhouse growers use substrates that have been already prepared by commercial potting mix manufacturers. Although others have looked at petunia growth response to specific substrate amendments to our knowledge, there are no reports on the

\begin{tabular}{llll}
\hline $\begin{array}{l}\text { Units } \\
\text { To convert U.S. to SI, } \\
\text { multiply by }\end{array}$ & U.S. unit & SI unit & $\begin{array}{l}\text { To convert SI to U.S., } \\
\text { multiply by }\end{array}$ \\
\hline 29.5735 & $\mathrm{fl} \mathrm{oz}$ & $\mathrm{mL}$ & 0.0338 \\
3.7854 & $\mathrm{gal}$ & $\mathrm{L}$ & 0.2642 \\
2.54 & inch $(\mathrm{es})$ & $\mathrm{cm}$ & 0.3937 \\
0.5 & $\mathrm{lb} / \mathrm{ton}$ & $\mathrm{kg} \cdot \mathrm{Mg}^{-1}$ & 2 \\
1 & $\mathrm{mmho} / \mathrm{cm}$ & $\mathrm{mS} \cdot \mathrm{cm}^{-1}$ & 1 \\
28.3495 & $\mathrm{oz}$ & $\mathrm{g}$ & 0.0353 \\
62.5000 & $\mathrm{oz} / \mathrm{lb}$ & $\mathrm{g} \cdot \mathrm{kg}^{-1}$ & 0.0160 \\
1 & $\mathrm{ppm}$ & $\mathrm{mg} \cdot \mathrm{L}^{-1}$ & 1 \\
$\left({ }^{\circ} \mathrm{F}-32\right) \div 1.8$ & ${ }^{\circ} \mathrm{F}$ & ${ }^{\circ} \mathrm{C}$ & $\left({ }^{\circ} \mathrm{C} \times 1.8\right)+32$
\end{tabular}


growth of petunia transplants in response to different commercially available substrates and their interaction with fertilizer regime.

The objective of this study was to evaluate petunia growth and flowering in response to different commercial substrates with two water sources (fertigation and clear water irrigation).

\section{Materials and methods}

Plant material and experimental DESIGN. The plant materials used in this experiment were 4-week-old seedlings of 'Bravo White' petunia. The plants were seeded into 200 -cell plug trays (20-mL cell volume) with LM-1 peat/ vermiculite propagation media (Lambert Peat Moss, Rivière-Ouelle, QC, Canada). Seedlings were placed in a glasshouse at Cornell University in Ithaca, NY (lat. $42^{\circ} \mathrm{N}$ ) with a temperature set point of $19^{\circ} \mathrm{C}$ under ambient light. Seedlings received fertilization three times weekly (Monday, Wednesday, and Friday) from $100 \mathrm{mg} \cdot \mathrm{L}^{-1}$ nitrogen from a water-soluble $21 \mathrm{~N}-$ 2.2P-16.6K fertilizer (Jack's Professional LX $^{\text {TM }}$ 21-5-20 All Purpose Water Soluble Fertilizer; J.R. Peters, Allentown, PA) and were watered as needed on the other days. The substrate experiment was performed in the same glasshouse again with a temperature set point of $19^{\circ} \mathrm{C}$ and with ambient light. The trial was performed as a $2 \times 7$ factorial evaluating two water sources (fertigation and clear water irrigation) and seven commercial substrates. The experiment was a completely randomized design with six singlepot replications per treatment. The seven commercial substrates used were SS (Sun Gro Horticulture), MM, AT (Terrenew, Geneva, NY), $\mathrm{CB}$ prepared on-site at Cornell University (Boodley and Sheldrake, 1982), and JO, LM-18, and LM-111 (Lambert Peat Moss). Component descriptions of these commercial substrates are shown in Table 1. Plants received one of two fertilizer treatments, either tap water or constant liquid fertilization (fertigation) using $150 \mathrm{mg} \cdot \mathrm{L}^{-1}$ nitrogen $21 \mathrm{~N}-2.2 \mathrm{P}-$ 16.6K fertilizer (Jack's Professional LX ${ }^{\mathrm{TM}}$ 2 1-5-20 All Purpose Water Soluble Fertilizer). The tap water, which was used as the water source for both the fertigation and clear water treatments had an alkalinity of $115 \mathrm{mg} \cdot \mathrm{L}^{-1}$ calcium carbonate $\left(\mathrm{CaCO}_{3}\right)$. On 11 Nov. 2012, uniform 4-week-old seedlings of petunia were transplanted into 6-inch-diameter round pots $(1.7 \mathrm{~L}$ volume) containing the aforementioned substrates. All pots were placed on raised benches. For the first $3 \mathrm{~d}$, all pots were overhead irrigated with clear water as needed. Thereafter, pots were overhead watered as needed according to treatment with either clear tap water or fertigation. All treatments were watered until substrate reached container capacity (i.e., until water just began to drip from the bottom of the pot). Plants were grown under natural daylength in late winter.

Data collection. Substrate leachate was collected weekly using the nondestructive PourThru extraction method (Wright, 1986). Substrate leachate $\mathrm{pH}$ was measured using a $\mathrm{pH}$ meter (pHTestr 20; Oakton Instruments, Vernon Hills, IL), and EC using an EC meter (ECTestr 11, Oakton Instruments). The $\mathrm{pH}$ and $\mathrm{EC}$ meters were calibrated daily. After 7 weeks, leachate elemental concentrations of $\mathrm{Ca}, \mathrm{K}, \mathrm{NH}_{4}{ }^{-} \mathrm{N}, \mathrm{NO}_{3}{ }^{-}-\mathrm{N}, \mathrm{Na}$, and chloride $(\mathrm{Cl})$ were measured using a multi-ion meter (CG001; CleanGrow, Vacaville, CA). The meter was calibrated with reference solutions. Leaf chlorophyll index (SPAD) was quantified for all plants using a nondestructive dual-wavelength chlorophyll meter (Minolta SPAD-502 chlorophyll meter; Spectrum Technologies, Plainfield, IL) by averaging measurements from three recently mature leaves per plant. Flower number (at anthesis of the first flower)

Table 1. Manufacturers, names, and component descriptions of seven commercial substrates studied to evaluate petunia growth and flowering in response to different commercial substrates with two water sources (fertigation and clear water irrigation). The experiment was performed as a $2 \times 7$ factorial evaluating two water sources and seven commercial substrates. On 11 Nov. 2012, uniform 4-week-old seedlings of petunia were transplanted into 6-inch-diameter $(15.2 \mathrm{~cm})$ round pots [ $1.7 \mathrm{~L}(0.45 \mathrm{gal})$ volume] containing the commercial substrates. For the first $3 \mathrm{~d}$ after petunia transplanting, all pots were overhead irrigated with clear water as needed. Thereafter, pots were overhead watered as needed according to treatment with either clear tap water or fertigation using $150 \mathrm{mg} \cdot \mathrm{L}^{-1}(\mathrm{ppm})$ nitrogen $21 \mathrm{~N}-2.2 \mathrm{P}-16.6 \mathrm{~K}$ fertilizer (Jack's Professional LX ${ }^{\mathrm{TM}}$ 21-5-20 All Purpose Water Soluble Fertilizer; J.R. Peters, Allentown, PA). All treatments were watered until substrate reached container capacity.

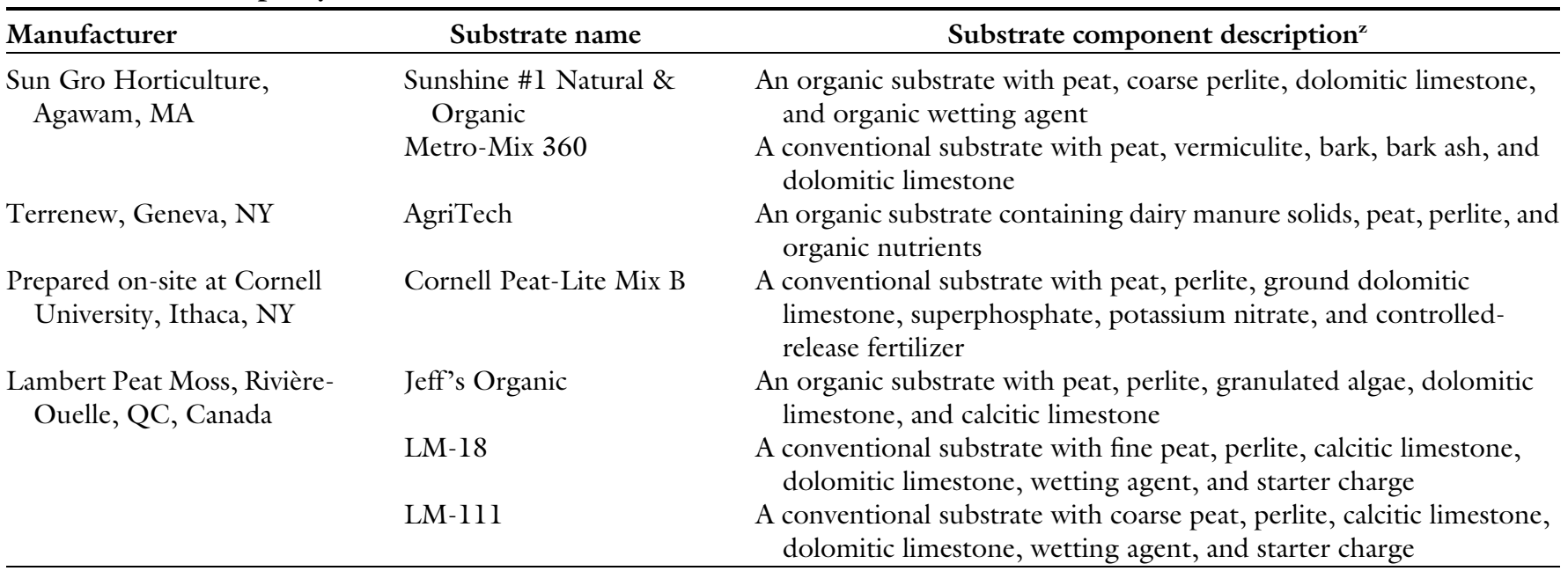

${ }^{\mathrm{z} C o m p o n e n t s ~ o f ~ C o r n e l l ~ P e a t-L i t e ~ M i x ~ B ~ r e p o r t e d ~ b y ~ B o o d l e y ~ a n d ~ S h e l d r a k e ~(1982), ~ w h e r e a s ~ o t h e r s ~ w e r e ~ o b t a i n e d ~ f r o m ~ t h e i r ~ r e s p e c t i v e ~ m a n u f a c t u r e r s . ~}$ 
was recorded. Plant shoots were removed from the container at the substrate surface and oven dried at $70{ }^{\circ} \mathrm{C}$ for $48 \mathrm{~h}$ to determine shoot DW. Root index was evaluated using a 0 to 5 scale, with 0 indicating no visible roots at the substrate surface and 5 indicating visible roots were matted on the surface of the substrate (Bi et al., 2009; $\mathrm{Li}$ and Mattson, 2015).

Statistical analysis. Two-way analyses of variance on data were performed using the general linear model program of SAS (proc GLM, version 9.3; SAS Institute, Cary, NC) to determine the main effect of substrate and water. Means were separated by Tukey's honestly significant difference test at $P \leq 0.05$.
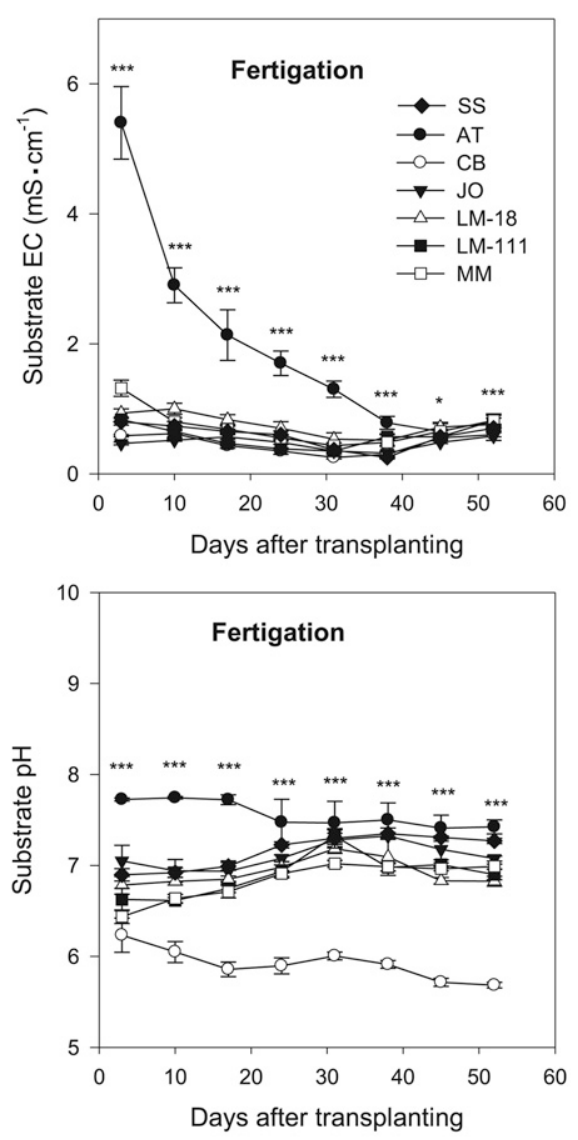

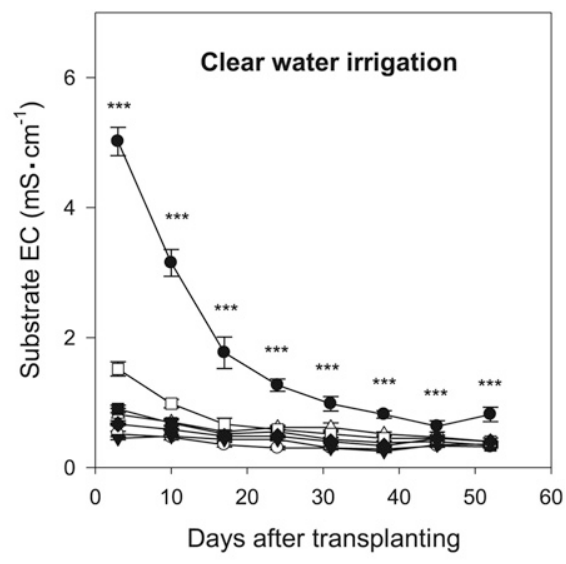

\section{Results and discussion}

Substrate EC AND PH values. The EC differed greatly among substrates, and to a lesser extent in response to fertilizer treatment (Fig. 1). With fertigation, substrate EC decreased over time to $38 \mathrm{DAT}$, and then did not further change. The AT substrate EC value was greater than others during the first 38 DAT. With clear water irrigation, substrate EC decreased over time to $31 \mathrm{DAT}$, and then did not further change. The AT substrate EC value was greater than other substrates during the entire petunia growth period. According to Table 1, AT substrate contains dairy manure solids, which could result in increased substrate EC. In general, EC values of $\mathrm{CB}$, JO, LM-18, LM-111, and SS substrates ranged between

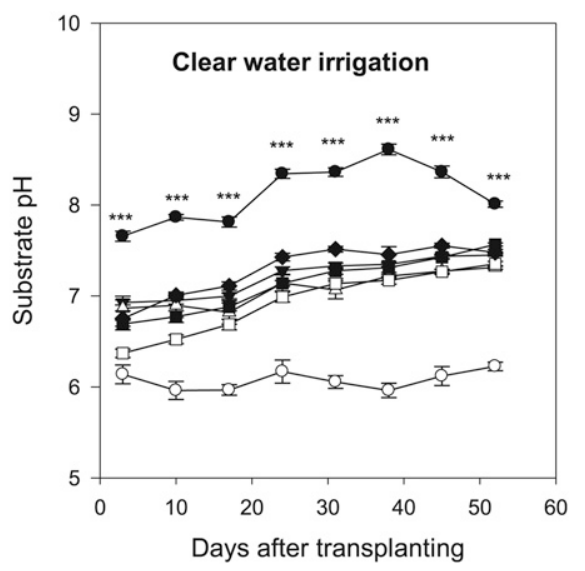

Fig. 1. Substrate leachate electrical conductivity (EC) and $\mathrm{pH}$ over time in response to substrate and fertigation/clear water irrigation treatments. Beginning from $3 \mathrm{~d}$ after transplanting, substrate leachate $\mathrm{EC}$ and $\mathrm{pH}$ values were measured weekly through PourThru method (Wright, 1986); SS = Sunshine \#1 Natural \& Organic (Sun Gro Horticulture, Agawam, MA), AT = AgriTech (Terrenew, Geneva, NY), CB = Cornell Peat-Lite Mix B prepared on-site at Cornell University (Ithaca, NY), JO = Jeff's Organic (Lambert Peat Moss, Rivière-Ouelle, QC, Canada), MM = Metro-Mix 360 (Sun Gro Horticulture). LM-18 and LM-111 are commercial substrates (Lambert Peat Moss). Vertical bars represent $\mathrm{SE}(\mathrm{n}=6)$; ${ }^{*} P<0.05,{ }^{* *} P<0.001 ; 1 \mathrm{mS} \cdot \mathrm{cm}^{-1}=1 \mathrm{mmho} / \mathrm{cm}$.

0.25 and $1.00 \mathrm{mS} \cdot \mathrm{cm}^{-1}$. The $\mathrm{MM}$ substrate EC ranged from 0.40 to $1.32 \mathrm{mS} \cdot \mathrm{cm}^{-1}$. The AT substrate EC was between 0.63 and $5.40 \mathrm{mS} \cdot \mathrm{cm}^{-1}$. The EC values quantify all salts dissolved in solution including fertilizer and nonfertilizer salts. These EC indicated that AT either had the highest fertility or highest nonfertilizer salts (or both) among the commercial substrates. Cavins et al. (2000) suggests that optimal EC for petunia according to PourThru extraction method is, between 2.0 and $3.5 \mathrm{mS} \cdot \mathrm{cm}^{-1}$. Thus, it would appear that for most substrates except AT, EC was not high enough for optimal growth of petunia plants even with the fertigation treatment.

Substrate $\mathrm{pH}$ is an important chemical property that strongly influences nutrient release in substrates (Ao et al., 2008; Yeager et al., 1983). The $\mathrm{pH}$ was affected by both substrate and fertilizer treatment (Fig. 1). With fertigation, all substrate $\mathrm{pH}$ values were between 6.5 and 7.5 , except AT and CB. The AT substrate (a dairy manure-based substrate) had the greatest $\mathrm{pH}$ ranging from 7.5 to 8.0 during the petunia growth period. The $\mathrm{CB}$ substrate exhibited the lowest $\mathrm{pH}$, which was between 5.8 and 6.3. Clear water irrigation had greater substrate $\mathrm{pH}$ values than fertigation. The decreased $\mathrm{pH}$ for the fertilizer treatment is likely because the fertilizer used is moderately acidic (potential acidity $390 \mathrm{lb} /$ ton $\mathrm{CaCO}_{3}$ equivalent), whereas the tap water used in this study had moderate alkalinity $\left(115 \mathrm{mg} \cdot \mathrm{L}^{-1} \mathrm{CaCO}_{3}\right.$ equivalent) (Camberato et al., 2013). In soilless substrate culture, optimal $\mathrm{pH}$ varies depending on plant species (Bunt, 1988). The suggested optimal substrate $\mathrm{pH}$ range for petunia is 5.46.2 because it is sensitive to iron and manganese toxicity at higher substrate $\mathrm{pH}$ (Argo, 2004; Cavins et al., 2000 ). Only the CB substrate gave an optimal $\mathrm{pH}$ for petunia during the experimental period.

SubSTRATE LEACHATE NUTRIENTS. Table 2 shows the elemental concentrations in leachate from different commercial substrates under fertigation or clear water irrigation as taken 52 DAT. There was a substrate and water interaction for $\mathrm{Ca}$, $\mathrm{K}, \mathrm{Na}, \mathrm{NH}_{4}{ }^{+}-\mathrm{N}$, and $\mathrm{NO}_{3}{ }^{-} \mathrm{N}$ concentrations in substrate leachate (Table 2). As expected, in many 


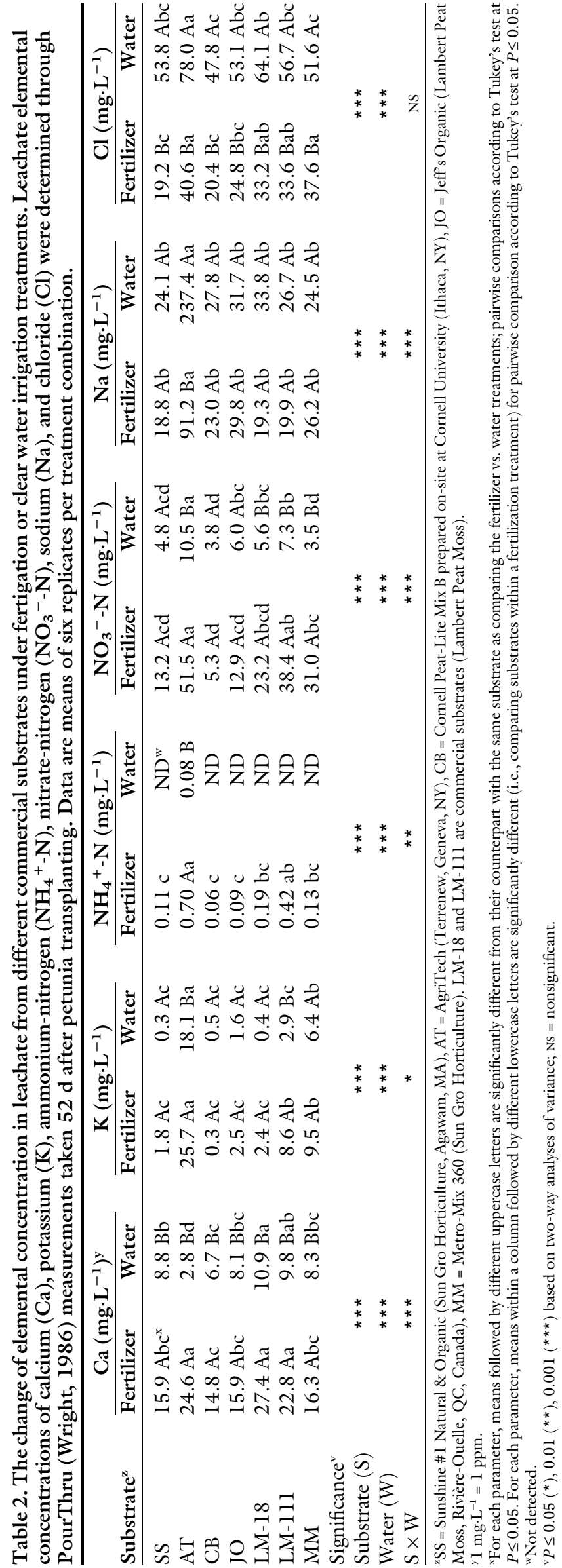

cases, elemental concentration was greater in the fertigation treatment than counterparts with the water treatment. Under fertigation treatment, leachate Ca concentrations of AT $\left(24.6 \mathrm{mg} \cdot \mathrm{L}^{-1}\right)$, LM-18 (27.4 $\left.\mathrm{mg} \cdot \mathrm{L}^{-1}\right)$, and $\mathrm{LM}-111\left(22.8 \mathrm{mg} \cdot \mathrm{L}^{-1}\right)$ were clearly higher compared with those of SS, CB, JO, and MM. With clear water irrigation, AT substrate leachate Ca concentration was lowest $\left(2.8 \mathrm{mg} \cdot \mathrm{L}^{-1}\right)$ among substrates; however, leachate $\mathrm{Ca}$ concentrations of LM-18 (10.9 mg. $\mathrm{L}^{-1}$ ) and LM-111 $\left(9.8 \mathrm{mg} \cdot \mathrm{L}^{-1}\right)$ were greater than those of others. Irrigation water source had effect on substrate leachate Ca concentration. Substrate leachate Ca concentration under fertigation was greater than clear water irrigation. As the fertilizer source did not contain $\mathrm{Ca}$, this indicated that clear water irrigation could result in substrate $\mathrm{Ca}$ leaching, causing plant $\mathrm{Ca}$ deficiency, especially in the AT substrate. The AT and LM-111 substrate leachate K concentrations under fertigation were greater than clear water irrigation. For SS, CB, JO, LM-18, and MM substrates, irrigation water source had no effect on leachate $K$ concentrations, which averaged $1.1,0.4,2.1,1.4$, and $8.0 \mathrm{mg} \cdot \mathrm{L}^{-1}$, respectively. With fertigation, leachate $\mathrm{K}$ concentrations of AT $\left(25.7 \mathrm{mg} \cdot \mathrm{L}^{-1}\right), \mathrm{LM}-111\left(8.6 \mathrm{mg} \cdot \mathrm{L}^{-1}\right)$, and $\mathrm{MM}\left(9.5 \mathrm{mg} \cdot \mathrm{L}^{-1}\right)$ substrates were greater than the other substrates. Similarly, leachate $\mathrm{K}$ concentrations of AT $\left(18.1 \mathrm{mg} \cdot \mathrm{L}^{-1}\right)$ and $\mathrm{MM}\left(6.4 \mathrm{mg} \cdot \mathrm{L}^{-1}\right)$ substrates under clear water irrigation were higher as compared with the other substrates.

With fertigation, AT and LM111 substrate leachate $\mathrm{NH}_{4}{ }^{+}-\mathrm{N}$ concentrations were greater than $\mathrm{SS}, \mathrm{CB}$, and $\mathrm{JO}$. The $\mathrm{NH}_{4}{ }^{+}-\mathrm{N}$ concentrations did not differ among SS, CB, JO, LM-18, and MM. With clear water irrigation, no $\mathrm{NH}_{4}{ }^{+}-\mathrm{N}$ was detected except from AT substrate. Leachate $\mathrm{NO}_{3}^{-}-\mathrm{N}$ concentrations of AT, LM18, LM-111, and MM substrates receiving fertigation were greater than clear water irrigation, but leachate $\mathrm{NO}_{3}{ }^{-}-\mathrm{N}$ concentrations of the other substrates were unaffected by irrigation water source. Regarding $\mathrm{NO}_{3}^{-}-$ $\mathrm{N}$, the AT and LM-11l substrate leachate $\mathrm{NO}_{3}{ }^{-}-\mathrm{N}$ concentrations were greater as compared with other substrates. This indicated that the AT and LM-111 mix either had more $\mathrm{NO}_{3}{ }^{-}-\mathrm{N}$ to begin with or was better at retaining 
$\mathrm{NO}_{3}{ }^{-}-\mathrm{N}$ throughout the experimental period.

Both substrate and fertilizer treatment and their interaction affected substrate leachate $\mathrm{Na}$ concentrations. The leachate $\mathrm{Na}$ concentration of AT substrate receiving clear water irrigation $\left(237.4 \mathrm{mg} \cdot \mathrm{L}^{-1}\right)$ was greater than fertigation $\left(91.2 \mathrm{mg} \cdot \mathrm{L}^{-1}\right)$. This suggests that the addition of fertilizer either led to increased leaching of $\mathrm{Na}$ from the container or increased plant uptake of $\mathrm{Na}$. Fertilizer treatment had no effect on leachate Na concentration of the other substrates. Meanwhile, the main effect of substrates affected leachate $\mathrm{Na}$ concentrations. The AT substrate had significantly higher substrate leachate $\mathrm{Na}$ concentration as compared with the other substrates. For SS, CB, JO, LM-18, and LM-111, leachate $\mathrm{Na}$ concentrations did not differ from one another and had an average value of $25.5 \mathrm{mg} \cdot \mathrm{L}^{-1}$. Substrate leachate $\mathrm{Cl}$ concentrations were affected by different commercial substrates and irrigation water sources, but not by their interaction. Clear water irrigation increased substrate leachate $\mathrm{Cl}$ concentration as compared with fertigation. With fertigation, $\mathrm{Cl}$ concentrations did not differ among AT, MM, LM-18, and LM111. The AT and MM substrate leachate $\mathrm{Cl}$ concentrations were greater than SS, CB, and JO. Under clear water irrigation, AT substrate leachate $\mathrm{Cl}$ concentration $\left(78.0 \mathrm{mg} \cdot \mathrm{L}^{-1}\right)$ was greatest among the substrates. The high $\mathrm{Na}$ and $\mathrm{Cl}$ concentrations in $\mathrm{AT}$ substrate may be due to the dairy manure solids as this was the only substrate to contain this amendment.

Petunia growth. Petunia DW and RI were affected by different commercial substrates and irrigation water source, but not by their interaction (Table 3 ). For all substrates, petunia DW and RI were greater when fertilizer was applied than clear water. For the seven substrates: SS, AT, CB, JO, LM-18, LMl11, and MM, petunia DW increased by $171 \%$, $32 \%, 157 \%, 124 \%, 76 \%, 90 \%$, and $157 \%$, respectively, if the plants were fertigated as compared with watered. This suggests that AT substrate followed by LM-18 and LMIII had the greatest nutrient charge incorporated into the substrate by the manufacturers. A grower fertigating with 150 $\mathrm{mg} \cdot \mathrm{L}^{-1} \mathrm{~N}$ can improve petunia $\mathrm{DW}$ and RI. With fertigation, petunias grown in AT substrate had the greatest DW, which was statistically the same as LM-18. Petunia DW did not differ between LM-18 and SS. Petunias grown in JO substrate had the lowest DW, and this was statistically the same as LM-11l and MM. With clear water irrigation, petunias grown in AT substrate had a greater DW than others. Petunias grown in LM18 substrate with clear water irrigation had a greater DW than SS, CB, JO, LM-111, and MM. Petunias grown in AT and LM-18 substrates receiving fertigation had a greater RI than others. Petunias grown in SS substrate with fertigation had a greater RI than CB, JO, LM-lll, and MM. With clear water irrigation, a similar trend for the substrates as in fertigated plants was found for petunia RI.

Petunia flower number was affected by different commercial substrates, irrigation water source, and their interaction (Table 3 ). The flower number of petunias grown in $\mathrm{SS}, \mathrm{CB}$, JO, LM-111, and MM substrates receiving fertigation was greater than clear water irrigation. However, the flower number of petunias grown in AT and LM-18 substrates was unaffected by irrigation water source, which averaged 8.3 and 4.1 flowers/ plant, respectively. The AT substrate had the greatest petunia flower number among all the substrates. James and van Iersel (2001) observed that N concentration in substrate affected petunia flower development. In addition, substrate components have also been found to affected petunia flower number. Arancon et al. (2008) found maximum number of flowers in substrates including $30 \%$ to $40 \%$

Table 3. Effects of different commercial substrates and irrigation water sources on petunia shoot dry weight (DW), root index (RI), flower number, and leaf chlorophyll index (SPAD) $52 \mathrm{~d}$ after petunia transplanting. The SPAD readings were measured using a chlorophyll meter (Minolta SPAD-502 chlorophyll meter; Spectrum Technologies, Plainfield, IL). Data are means of six replicates per treatment combination.

\begin{tabular}{|c|c|c|c|c|c|c|c|c|}
\hline \multirow[b]{2}{*}{ Substrate $^{\mathrm{z}}$} & \multicolumn{2}{|c|}{$\mathrm{DW}(\mathrm{g} / \text { plant })^{\mathrm{y}}$} & \multicolumn{2}{|c|}{ RI ( $0-5$ scale $)^{x}$} & \multicolumn{2}{|c|}{ Flowers (no./plant) } & \multicolumn{2}{|c|}{ SPAD } \\
\hline & Fertilizer & Water & Fertilizer & Water & Fertilizer & Water & Fertilizer & Water \\
\hline SS & $2.14 \mathrm{Abc}^{\mathrm{w}}$ & $0.79 \mathrm{Bc}$ & $3.67 \mathrm{Ab}$ & $2.08 \mathrm{Bc}$ & $7.3 \mathrm{Aab}$ & $1.3 \mathrm{Bb}$ & 39.7 Aab & $37.1 \mathrm{Aa}$ \\
\hline $\mathrm{CB}$ & 1.77 Acd & $0.69 \mathrm{Bc}$ & $3.17 \mathrm{Ac}$ & $2.00 \mathrm{Bc}$ & $3.8 \mathrm{Ac}$ & $1.3 \mathrm{Bb}$ & $41.2 \mathrm{Aa}$ & $38.7 \mathrm{Aa}$ \\
\hline $\mathrm{JO}$ & $1.21 \mathrm{Ae}$ & $0.54 \mathrm{Bc}$ & $2.75 \mathrm{Ac}$ & $1.50 \mathrm{Bd}$ & $2.3 \mathrm{Ac}$ & $0.7 \mathrm{Bb}$ & $36.3 \mathrm{Aab}$ & $36.9 \mathrm{Aa}$ \\
\hline LM-18 & $2.58 \mathrm{Aab}$ & $1.47 \mathrm{Bb}$ & $4.17 \mathrm{Aa}$ & $3.08 \mathrm{Bb}$ & $5.0 \mathrm{Abc}$ & $3.2 \mathrm{Ab}$ & $40.3 \mathrm{Aab}$ & $36.3 \mathrm{Aa}$ \\
\hline Significance $^{\mathrm{v}}$ & & & & & & & & \\
\hline Substrate $(S)$ & \multicolumn{2}{|c|}{$* * *$} & \multicolumn{2}{|c|}{$* * *$} & \multicolumn{2}{|c|}{$* * *$} & \multicolumn{2}{|c|}{$* * *$} \\
\hline Water $(\mathrm{W})$ & \multicolumn{2}{|c|}{$* * *$} & \multicolumn{2}{|c|}{$* * *$} & \multicolumn{2}{|c|}{$* * *$} & \multicolumn{2}{|c|}{ NS } \\
\hline$S \times W$ & \multicolumn{2}{|c|}{ NS } & \multicolumn{2}{|c|}{ NS } & \multicolumn{2}{|c|}{ * } & \multicolumn{2}{|c|}{ * } \\
\hline
\end{tabular}

${ }^{2}$ SS = Sunshine \#l Natural \& Organic (Sun Gro Horticulture, Agawam, MA), AT = AgriTech (Terrenew, Geneva, NY), CB = Cornell Peat-Lite Mix B prepared on-site at Cornell University (Ithaca, NY), JO = Jeff's Organic (Lambert Peat Moss, Rivière-Ouelle, QC, Canada), MM = Metro-Mix 360 (Sun Gro Horticulture). LM-18 and LM-111 are commercial substrates (Lambert Peat Moss).

y $1 \mathrm{~g}=0.0353 \mathrm{oz}$.

${ }^{\mathrm{x}} 0=$ no visible at the substrate surfaces, $5=$ visible roots were matted on the surface of the substrate.

"For each parameter, means followed by different uppercase letters are significantly different from their counterpart with the same substrate as comparing the fertilizer vs. water treatments; pairwise comparisons according to Tukey's test at $P \leq 0.05$. For each parameter, means within a column followed by different lowercase letters are significantly different (i.e., comparing substrates within a fertilization treatment) for pairwise comparison according to Tukey's test at $P \leq 0.05$.

${ }^{v} P \leq 0.05\left(^{*}\right), 0.01\left(^{* *}\right), 0.001\left(^{* *}\right)$ based on two-way analyses of variance; NS $=$ nonsignificant. 
vermicompost and at levels greater than $40 \%$ vermicompost, a decrease in flower production was observed. However, the substrate including 5\% to $50 \%$ dewatered aquaculture effluent was not found to affect petunia flower number (Danaher et al., 2013).

There was a substrate and water interaction for petunia SPAD readings (Table 3 ). The SPAD readings of petunia grown in AT substrate were less when fertigation (21.3) was used than clear water irrigation (26.8), but water source had no effect on the SPAD readings of petunia grown in the other substrates. The main effect of substrates affected petunia SPAD readings. With fertigation, SPAD reading of petunia grown in CB substrate (41.2) was greater than LM111 (35.5) and AT substrates, but this was statistically the same as SS, JO, LM-18, and MM. The SPAD reading of petunia grown in AT substrate was the lowest among all the substrates. With clear water irrigation, SPAD reading of petunia grown in AT substrate was less than the other substrates. Petunias grown in AT substrate were observed to have interveinal leaf chlorosis as compared with the other substrates. The high $\mathrm{pH}$ value of AT substrate could result in iron deficiency (Camberato et al., 2013). Some studies found a high correlation between low iron concentration in the leaf and reduced chlorophyll index using a SPAD meter (Álvarez-Fernández et al., 2005; Peryea and Kammereck, 1997).

\section{Conclusions}

Among all the substrates, DW, $\mathrm{RI}$, and flower number of petunia grown in AT substrate were greatest, but the SPAD reading was the lowest under either fertigation or clear water irrigation treatments. Although AT, a dairy manure-based substrate, led to greatest plant growth measurements, additional steps need to be taken to ensure $\mathrm{pH}$ and micronutrient availability to plant are optimized. For SS, MM, CB, JO, LM-18, and LM-111 substrates, fertigation increased petunia DW, $\mathrm{RI}$, and flower number as compared with clear water irrigation, but not SPAD chlorophyll index. The different commercial substrates studied in this experiment dramatically affected petunia growth and flowering. Differences in growth (DW, RI, and flower number) according to substrate were especially apparent for unfertilized plants and serve to highlight that commercial substrates vary greatly in their nutrient supply and retention. But, even when plants received continuous fertigation, substrate choice had a substantial effect on final plant size and quality. For example, DW varied from 1.21 to $3.03 \mathrm{~g}$. These findings suggest that selection of commercial substrate can play a large role in subsequent plant performance in production of containerized greenhouse plants. Commercial greenhouse industry members should conduct inhouse trials of substrates to select one that performs well in their growing environment and with their fertilization practices.

\section{Literature cited}

Abad, M., P. Noguera, R. Puchades, A. Maquieira, and V. Noguera. 2002. Physicochemical and chemical properties of some coconut coir dusts for use as a peat substitute for containerised ornamental plants. Bioresour. Technol. 82:241-245.

Álvarez-Fernández, A., S. García-Marco, and J.J. Lucena. 2005. Evaluation of syntheticiron(III) chelates (EDDHA/ $/ e^{3+}$, EDDHMA/ $\mathrm{Fe}^{3+}$ and the novel EDDHSA/ $\left.\mathrm{Fe}^{3+}\right)$ to correct iron chlorosis. Eur. J. Agron. 22:119-130.

Ao, Y., M. Sun, and Y. Li. 2008. Effect of organic substrates on available elemental contents in nutrient solution. Bioresour. Technol. 99:5006-5010.

Arancon, N.Q., C.A. Edward, A. Babenko, J. Cannon, and J.D. Metzger. 2008. Influence of vermicomposts produced by microorganisms from cattle manure, food waste and paper waste on the germination, growth and flowering of petunias in the greenhouse. Appl. Soil Ecol. 39:91-98.

Argo, B. 2004. Understanding pH management and plant nutrition. Part 4 . Substrates. J. Intl. Phalaenopsis Alliance 13:1-5.

Argo, W.R. and J.A. Biernbaum. 1996. Availability and persistence of macronutrients from lime and preplant nutrient charge fertilizers in peat-based root media. J. Amer. Soc. Hort. Sci. 121:453460.

Atiyeh, R.M., C.A. Edwards, S. Subler, and J.D. Metzger. 2001. Pig manure vermicompost as a component of a horticultural bedding plant medium: Effects on physicochemical properties and plant growth. Bioresour. Technol. 78:11-20.

Benito, M., A. Masaguer, A. Moliner, and R. De Antonio. 2006. Chemical and physical properties of pruning waste compost and their seasonal variability. Bioresour. Technol. 97:2071-2076.

Bi, G., W.B. Evans, and G.B. Fain. 2009. Use of pulp mill ash as a substrate component for greenhouse production of marigold. HortScience 44:183-187.

Boodley, J.W. and R. Sheldrake. 1982. Cornell peat-lite mixes for commercial plant growing. Cornell Coop. Ext. Publ., Info. Bul. 43.

Bunt, A.C. 1988. Media and mixes for container-grown plants. 2nd ed. Unwin Hyman, London, UK.

Camberato, D.M., J.J. Camberato, and R.G. Lopez. 2013. Comparing the adequacy of controlled-release and water-soluble fertilizer for bedding plant production. HortScience 48:556-562.

Cavins, T.J., B.E. Whipker, W.C. Fonteno, B. Harden, I. McCall, and J.L. Gibson. 2000. Monitoring and managing $\mathrm{pH}$ and EC using the PourThru extraction method. North Carolina State Univ. Coop. Ext. Serv. Bul. 590.

Danaher, J.J., J.M. Pickens, J.L. Sibley, J.A. Chappell, T.R. Hanson, and C.E. Boyd. 2013. Petunia growth response to container substrate amended with dewatered aquaculture effluent. HortTechnology 23:57-63.

Garcia-Ortuño, T., J. Andreu-Rodriguez, M.T. Ferrandez-Garcia, C.E. FerrandezGarcia, E. Medina, C. Paredes, M.D. Perez-Murcia, and J. Moreno-Caselles. 2012. Evaluation of the different uses of Washingtonia robusta pruning waste. Commun. Soil Sci. Plant Anal. 44:623631.

Ghehsareh, A., M. Hematian, and M. Kalbasi. 2012. Comparison of datepalm wastes and perlite as culture substrates on growing indices in greenhouse cucumber. Intl. J. Recycling Organic Waste Agr. 1:1-4.

Hernández-Apaolaza, L., A.M. Gascó, J.M. Gascó, and F. Guerrero. 2005. Reuse of waste materials as growing media for ornamental plants. Bioresour. Technol. 96:125-131.

Higashikawa, F.S., C.A. Silva, and W. Bettiol. 2010. Chemical and physical properties of organic residues. Rev. Bras. Cienc. Solo 34:1742-1752.

James, E.C. and M.W. van Iersel. 2001. Fertilizer concentration affects growth and flowering of subirrigated petunias and begonias. HortScience 36:40-44. 
Li, Y. and N.S. Mattson. 2015. Effects of seaweed extract application rate and method on post-production life of petunia and tomato transplants. HortTechnology 25:505510.

Peryea, F. and R. Kammereck. 1997. Use of Minolta SPAD-502 chlorophyll meter to quantify the effectiveness of mid-summer trunk injection of iron on chlorotic pear trees. J. Plant Nutr. 20:1457-1463.
Raviv, M. 2013. Composts in growing media: What's new and what's next? Acta Hort. 982:39-52.

U.S. Department of Agriculture. 2014. Floriculture crops 2013 summary. U.S. Dept. Agr., Natl. Agr. Stat. Serv., Washington, DC.

Wright, R.D. 1986. The pour-through nutrient extraction procedure. HortScience 21:227-229.
Yeager, T.H., R.D. Wright, and S.J. Donohue. 1983. Comparison of pourthrough and saturated pine bark extract $\mathrm{N}, \mathrm{P}, \mathrm{K}$, and pH levels. J. Amer. Soc. Hort. Sci. 108:112-114.

Zaller, J.G. 2007. Vermicompost as a substitute for peat in potting media: Effects on germination, biomass allocation, yields and fruit quality of three tomato varieties. Scientia Hort. 112:191199. 